\title{
Socio-Economic and Psychological Impacts of Covid-19: A Case Study of Quarantined Village Ziarat Talash in Dir Lower, Pakistan
}

\author{
Azizullah Jan ${ }^{1 *}$, Khalil U. Rahman ${ }^{2}$ and Ihsan Ullah Khan ${ }^{3}$ \\ 1. Department of Sociology, University of Peshawar, Peshawar Pakistan. \\ 2. Department of Sociology, Hazara University, Mansehra, Pakistan. \\ 3. Department of Sociology, FATA University, Kohat, Pakistan.
}

\begin{abstract}
The global outbreak of coronavirus is conclusively attributed to the direct contacts and social interactions of individuals with one another. Because of the fatal nature of the virus and man being the major host for the virus, scientists have embarked upon/ intimidated people to practice social distancing so that the further spreading of the virus may be stopped. Such social distancing, including self-isolation, restriction of movement, lockdown, and quarantine has brought enormous social disruption in the lives of people. This paper aims to explore the social, psychological, and economic impacts of social distancing on the lives of the inhabitants in a quarantined village Ziarat Talash in District Dir Lower, Khyber Pakhtunkhwa Province of Pakistan. For this purpose, 08 potential respondents in the mentioned village were purposively selected and their views were taken through in-depth interviewing. The collected data was analysed and the interviews were clubbed into three major themes including social, psychological, and economic impacts of self-isolation and quarantined life in the targeted locale of the study. It is concluded that self-isolation and social distancing through quarantine has seriously disrupted the social, economic, and psychological aspects of the inhabitants in the area.
\end{abstract}

Keywords: Coronavirus, Interactions, Quarantine, Lockdown, Disruption, Inhabitants.

\section{Introduction}

The pandemic caused by COVID-19 was initially triggered in December 2019 in Wuhan city, Hubei province of China. It spread with enormous speed and ratio and expected to be further spread across the world. Initially the epicentre of the outbreak was China for the first few weeks after the virus was detected but later on travelled across regions and countries (Li et al., 2020). The virus with different ratio and intensity has affected almost all the countries of the world. According to the observed cases, suspected cases and deaths occurred; the initial epicentre of the virus was China then Iran and Italy and recently shifted to the United States, UK, France, and Spain. The most affected of those regions so far are Iran, Italy, Japan, South Korea, and USA where people suffered from the virus were reported heavily in relations to other parts of the world. Even though the cases reported from China are expected to have peaked in the previous three months but it has been reported that the locally transmitted cases within the country are now falling (WHO, 2020). The control on the spread in China is attributed to the high standard of health facilities, 
administrative measures, large public awareness, and sensitization that helped China to overcome the biggest challenge posed by the invisible creature. While some countries have been able to effectively treat the reported cases, it is uncertain how future spread may be effectively dealt with, to curb the pandemic in targeted regions. Amidst the significant public health risk posed by COVID-19, World Health Organization (WHO) has declared a public health emergency of international concern to ensure international responses to the pandemic. It is however, currently debated whether COVID-19 could potentially escalate to inflict more damages and harms to the world (Warwick \& Roshen, 2020).

The scientists and researchers are struggling hard to find out a solution to this pandemic however, no or less success has been witnessed so far in this regard. The best possible suggested measure is to practice social distancing and self-isolation because the virus has been found as very contagious that can easily be spread from one human to another through social contacts, shaking hands, sneezing, and coughing. Without an antibody to forestall, the infection's spread, social separating - a measure considered best to slow its spread - is rethinking current life. Infections and pandemics are as old as human civilization. Across human history, the irresistible infections have influenced civilizations and changed the course of humankind (Joffre \& Lee, 2004). For example, the Black Death in Europe (1347-1351) murdered around 25 million individuals. During the old times, human beings developed peculiar habits, beliefs, and strategy to cope with the posing threats of a particular disease. For example, contrite Christians walked through the lanes of Europe beating themselves to pacify God.

Likewise, precautionary measures, strategies, and practices have been largely evolved to cope with the pandemics in the contemporary world. For example, in the context of the current pandemic of COVID-19, the scientist and medical specialists are suggesting community and personal hygiene measure to ensure personal and public safety. It is highly advisable that covering faces and noses by wearing masks, using sanitizers, hand washing and covering mouth while coughing and sneezing are the suggested measure to overcome the challenge of Covid19. Likewise, some other safety measures are suggested including the practice of social distancing self-isolation and administratively imposed quarantine (Chen et al., 2020; Fong et al., 2020). Although social isolation and separation have been found as tested remedies for managing irresistible health condition. However, isolating individuals from groups, family members and larger society may negatively affect the prosperity and psychological wellness. An extensive review of 24 different investigated cases, a negative association was found between isolation and mental health (Brook et al., 2020). Similarly, a negative connection was also found between restricted gatherings and sense of powerlessness that may further leads to uneasiness (Jeong et al., 2016).

The travel restrictions undoubtedly had a role in reducing exportations of infections and delayed the onset of outbreaks (Quilty et al., 2020; Tean et al., 2020). Person-to-person transmission is mostly driven by who interacts with Riou et al. (2020) and Chan et al. (2020) which can vary by age and location of the contact (school, work, home, and community). Under the context of a large-scale on-going outbreak, contact patterns would drastically shift from their baseline conditions. In the COVID-19 outbreak in Wuhan, physical distancing measures, including but not limited to school and workplace closures and health promotions that encourage the public to avoid crowded places, are designed to drastically shift social mixing patterns, and are often used in epidemic settings (Fong et al., 2020). Although contact patterns can be inferred from reported social contact data that include information on which setting the contact took place. Such studies are often focused on high-income countries, or particular high- 
density areas (Mossong et al., 2008; Zhang, 2019). This limitation can be addressed by quantifying contact patterns in the home, school, work and other locations across a range of countries based on available information from household-level data and local population demographic structures (Prem, 2017).

\subsection{Situation in Pakistan}

The first reported case of coronavirus was reported in Pakistan in the last week of March 2020. According to the initial information regarding the reported cases, it was conclusively reported that the virus is perceived to significantly affect the urban population because of the large-scale movement, frequent interaction, and larger dynamic density in the cities. However, the cases of coronavirus have begun started to report in the sub urban and semi-sural settings and population of the country. Initially, it was viewed that small villages and scattered population especially in the rural areas will be likely less affected but because of the high probability of transmission of the virus from one person to another, the disease was also spread among the far off rural communities in various provinces of Pakistan. Initially, the most affected districts of the Khyber Pakhtunkhwa Province of Pakistan were Peshawar, Nowshera, Charsaddah, Mardan, and Dir lower. The cases were primarily reported in the urban centres of the district however, villages were equally affected from the coronavirus.

The table-1 depicts the ratio of the increasing Covid-19 patients in the Khyber Pakhtunkhwa province of Pakistan. It reflects that the patients increased with geometrical progression, which is very dangerous for social life. The table also indicated that how fast the Covid-19 spread and how quickly it effects the human body.

Table-1: Corona Cases in Khyber Pakhtunkhwa and Dir Lower

\begin{tabular}{|l|c|c|c|c|c|c|c|}
\hline Region/Area & $\begin{array}{l}\text { Suspecte } \\
\text { d Cases }\end{array}$ & $\begin{array}{l}\text { Total } \\
\text { Death }\end{array}$ & $\begin{array}{l}\text { Confirmed } \\
\text { Cases }\end{array}$ & $\begin{array}{l}\text { Negative } \\
\text { Cases }\end{array}$ & $\begin{array}{l}\text { Recovered } \\
\text { Cases }\end{array}$ & $\begin{array}{l}\text { Total tests } \\
\text { Conducted }\end{array}$ & $\begin{array}{l}\text { Total in } \\
\text { Districts }\end{array}$ \\
\hline $\begin{array}{l}\text { Khyber } \\
\text { Pakhtunkhwa }\end{array}$ & 1226 & 17 & 459 & 970 & 54 & 3655 & 34 \\
\hline Dir Lower & 8 & 1 & 15 & 26 & 2 & 49 & 34 \\
\hline
\end{tabular}

Source: Directorate General Health Services, Khyber Pakhtunkhwa. Dated; 07/04/2020

District Dir (Lower) is situated in the North of Pakistan nearly $150 \mathrm{KM}$ away from the capital city of the Khyber Pakhtunkhwa Province of Pakistan. Headquarter of the district is the Taimargarah city which is relatively the biggest urban centre in the District. District Dir (Lower) is mostly comprised of rural settings where majority of the inhabitant's lives in the hilly areas and the population is mostly scattered in small villages and hamlets. Village Ziarat of Tehsil Taimargarah is one of the villages in the district mainly with scattered households and lowest congestion in term of households and population. Because of the nature of population composition and isolated households, it was considered that the inhabitants of the village would be having more chances to remain safe from the infection of the COVID-19. It is because, the inhabitants of the village have limited contacts with the urban centres of the province, and they are entirely dependent on their farms and small-scale business for their income and livelihood.

Despite all the mentioned factors, village Ziarat Talash got its first coronavirus case when a female returnee from Hajj was detected as Corona positive. This news shocked the inhabitants and a sense of extreme fear and threat was prevailed among the inhabitants. The district 
administration strived hard to prevent the spread of virus in the village. All the family members of the infected person were kept in quarantine/isolation and the villagers were advised to restrict their movement and follow the WHO safety precautions for COVID-19. In order to keep the situation in control, the district administration ultimately took a decision to quarantine the entire village, which has 700 households. During this period, mass mobility was contained, shops were closed, and the people were advised to pray in their homes in place of attending mosques. All the social gatherings including funeral prayers, marriage ceremonies, attending Jirga were completely banned so that the chain of the coronavirus may be broken to protect the lives of the inhabitants.

\subsection{Significance of the Study}

Coronavirus has brought unprecedented harm to individuals, families, communities, and societies. It has negatively affected the social, economic, and psychological aspects of human life on a large scale. However, the pandemic caused by the virus has also brought serious negative outcomes for the small-scale communities including hamlets and villages. The largescale impacts have been documented and the scientist to calculate the harms and negative impacts of the COVID-19 has applied various statistical models. However, it is pertinent to document the hardships and difficulties experienced by the inhabitants of a typical traditional and small-scale village to ascertain the severity of the socio-psychological impacts of COVID19 at a grass root level especially in the natural settings.

It is a commonly held view that this pandemic has a serious health and physical consequences on human lives, however it has created an enormous social and psychological distress in nooks and crannies of the world. It has seriously affected the social structure and social fabric of the society by potentially paralysing the education, family, political and social sectors across the world. Similarly, it is generally believed that coronavirus has negatively affected the socio economic and psychological aspect of life structure of a Pakistani society. Some people believe that the spread of Covid-19 is more serious and psychologically threating than the social and political disaster of the infamous event of $9 / 11$. It is radically changing contemporary life, penetrating its social, political, and monetary dimensions.

The on-going pandemic across the world has enormous physical, biological, social, psychological, and economic repercussions across the world. Scientists and experts of different fields are striving hard through integrated coordination to reach out a feasible solution to get rid of this situation. The best possible measures suggested by the policy makers and world health organization are social distancing, self-isolation and quarantine. However, individuals, families, and community who are affected or perceived to have some contacts with the infected individuals have come to the limelight in particular. Every one look and perceive the individual, group or family as a potential threat to the entire community especially the village or any specific street is socially isolated and to the some extent stigmatized and labelled as being infected. Such social situation creates a significant negative impact both socially and psychologically. The infected individuals feel as isolated, helpless, and alienated and entirely depend upon the help and assistance of other. In view of the above-mentioned social conditions, it was planned to carry out a systematic study to underscore the social and psychological implication of the Covid-19. For this purpose, we envisioned that the best possible place to collect data in quarantined community so that their daily life difficulties may be explored. The research question for the study designed in the way that either people in quarantine spent a comfortable life. In addition, the circumstance around that area is allowed for daily routine. 


\section{Research Methodology}

The selected locale for the study was the village of Ziarat Talash situated in District Lower Dir, Khyber Pakhtunkhwa province of Pakistan. After reporting of few suspected cases in the village, the district management and local government declared that the village might be quarantined so, that the confirmation of the infected cases may be made and further spread of the diseases may be stopped. According to the data conducted in the Census survey of year 2018, there are 729 households in the village of Ziarat Talash, district lower Dir. The specialists utilized purposive examining methods to gather pertinent data from focused respondents (Creswell, 2010). The semi-organized meeting guide was utilized as a tool for collecting data from respondents. Bryman (2012) has referred to the very structure of the in-depth interviews and held the view that a semi-structured interview provides an opportunity for both the interviewers and interviewees to supplement additional knowledge, which could give a new direction. The researchers were composing notes (jottings) with full fixation and concentrated on the mentality, reactions and on their feelings when the scientist was meeting the members. The scientist gave full opportunity to the members in their noting time; the specialist did not meddle in any of their answers. The information was broken down through translating the information and distinguishing proof of topics for understanding, the topical investigation offers accentuation to inspecting, pinpointing and designs from the information (Creswell, 2010). These themes in the information were noteworthy to the clarification of the reality associated with the research questions. Individual perception and past writing were additionally remembered for the subjective information investigation to comprehend the perspectives on the respondents.

\section{Impacts of Coronavirus in Pakistan}

\subsection{Social Impacts}

According to the UN (2020), the outbreak of COVID-19 has affected all segments of the society and especially harmful to the members of social groups including vulnerable, marginalized and poor. The situation may continue to affect groups such as vulnerable including individuals with low income, elder members, youth, people with disabilities and indigenous population. Early Evidence collected indicates that the social and economic impacts of the pandemic are being borne disproportionately by destitute and indigenous people. The UNI has further informed that the negative social impacts of the pandemic many be further detreated if appropriate policy measure were not being put in place. Holistic and comprehensive social protection systems may play a durable role in the protection of the poor masses.

The village communities thrive on social relationships, the day today interaction, cooperation, and coordination. They have very little monetary resources but they possess strong wealth in the form of social capital and social asset. They feel socially protected when they meet one another in routine, discuss their difficulties, extending their support in time of need. Moreover, they also share happiness and sorrows with one another and soliciting the support of other in the time of ebb and flow. The overall society is effected by this burning issue, which is not confined to any aspect of society but the social life. It is the key for the dynamism, and progress of society is highly affected. One of the respondents expressed that:

"Our social life is very disturbed by this pandemic and we are unable to participate in the funeral prayers of our relatives. How an individual or a family can bear the loss of 
loved one alone if not supported by friends, relatives and neighbours. During this quarantine time, we perceive that we might not be able to attend funeral prays to light the burden of our neighbours and relatives. Such situation has made us worried. Life in a quarantined village is full of hurdles, threats, and difficulties."

Being social and cultural, tied inhabitants find it painful to bear a difficult time alone. They find strength when they are among their fellow villagers. They do not think that they will be alone in the time of difficulties but the time they spend in quarantine was a bad and a painful experience. For instance, as indicated from the above interview that participation in the funeral prayers is not only a religious obligation but also a moral, social responsibility and a type of psychological comfort for the bereaved family. Villagers warmly participate in such gatherings and they expect their neighbours will reciprocate them similarly. Therefore, we can say that these kinds of social cultural and religious significant ceremonies, gatherings, and practices are highly affected due to this pandemic. Regarding the social impact of quarantine, one of the respondent revealed that:

"We are restricted to our homes to such an extent that we have been advised to perform our prayers at home. Our Mosques are closed where we used to offer our prayers five time a day. We meet one another and ask about the daily problems we face in our live. We support and help one another. This is the most difficult time but unfortunately, we cannot meet to help one another. Likewise, our life is an intense trouble because we are not allowed to go outside of our home even if it is highly needed".

Attending mosque carries an important social and cultural significance especially in the rural settings. Mosque is not only considered a religious centre but it also carries a significant meaning in terms of social gathering and social welfare. Muslims usually performs five-time prayers in Masjid (mosque) on a daily basis. The places of worship are closed due to this pandemic, which is highly unbearable in a society where the majority of people are associated with religion and religious teachings. According to Nisar \& Rashid (2019), worship in mosque creates solidarity and social cohesion among the people of society. Therefore, it may be inferred that this pandemic has directly affected community life and created a social gape among the inhabitants.

Educational institutions play a vital role in socialization and culture transmission to the next generation. One of the respondents exposed:

"The institutes of education are closed due to the spreading of coronavirus. It caused a bad impression on the overall educational development and progress. The schools, colleges, and universities throughout the country are closed which badly affects the grooming of students and children in the future. It means that hurdles are created in the way to achieve our educational goals in this educational year.

This issue is very crucial because the development of a nation is measure with the parameter of educational qualities, development, and progress. The people are unwilling to send their children to school in this critical situation. Everybody is afraid in this regard that to escape themselves as much more as possible. McCormack (1997) find out that education is key to the progress and betterment of society. In addition, he highlighted that education imparts the upcoming generation to combat the difficulties and obstacles faced to people and society. 
Social network is the part of life for normal routine in any society. While a fault in this network is very destructive in the sense of aloofness and social isolation. These dilemmas create a huge gap in the smooth running and dynamism of life. Meeting, interacting, and interdependency strengthen the whole social life of human beings. Another respondent stated:

"Social relations and other activities related to conjugal relations are also suffered due to this pandemic. Marriage ceremonies and engagement programs are delayed and prohibited in quarantine which is quite unbearable"

Social relation in the form of marriage and engagement has also occurred in our daily life. Such a kind of activities is also prohibited and not allowed in quarantine life. These functions also become the causes of coronavirus transferred to another human being body. These activities are banned for the sack to bring control over the spreading of COVID-19.

\subsection{Psychological Impact}

Fear, stress, and anxiety are considered as natural and normal reactions in an uncertain condition. The psychological implication of COVID-19 is potentially binding on the individuals, families and communities. Negative psychological forces sprouts in such a situation where people are being kept isolated and they cannot share their difficulties with one another. Such situations are more likely to be happened with people already facing problems of low resources, stability, and family finance. Continuous and persistent worries, overwhelmed emotions, concerns about health and family finance, restlessness and irritability may be the consequences of imposed social isolation. In such situation, psychological support is necessary in the way to accomplish the daily base tasks and responsibilities. While in contrast to moral support, people lose their mental and physical strength to perform their responsibilities positively. One of the respondents discussed:

"As far as my thinking is concerned, everyone in the village will be having a difficult time. We are away from one another is a problem but meeting one another is even a bigger problem as we have been told about. The neighbours are uncertain when this situation will end up. Do the life will return to normal is not clear to anyone. On the other hand, we have been advised that we must be cautious about meeting others if even this quarantine is over. Life has become difficult and things are not as easy as before”.

The daily life experiences of the study participants shows some psychological distress and restlessness. As evident from the above narratives, people are quite uncertain about their activities, future and life. The psychological implications of the social isolation seems quite imposing and they have a difficult time to navigate through the difficult condition. Trust and moral support is also very beneficial in respect to perform and accomplish the responsibilities of a person. Lack of trust upon one another is hazardous in this regard because people feel fear to meet with each other. One of the respondents highlighted:

"The people live in quarantine face the health-related problems because majority of elders are suffering due to blood pressure, diabetics, heart diseases, and some other chronic diseases. The people in quarantine are extremely in a very rough position because they are not allowed to go to Bazar or other places of the market".

Another aspect that further added to the difficulties of the study participants was looking after 
the sick and elders in their homes. Care about health is most important for the survival of life because people in quarantine are required to remain in homes and confine their interaction with other members of communities. People in quarantine confronted difficulties related to public health care. One-third population grappled in quarantine are aged and they have various health problems like blood pressure, heart disease, and other chronic illness. They survive on medicines and other health care facilities. Unfortunately, they are not able to go the outside and bring medicines.

"Such away one of the respondents said that quarantine has limited not only our movement but the whole life came to standstill. Ranging from social interaction to public gathering, from ceremonial activities to customs and traditions of daily life are halted because of this pandemic".

\subsection{Economic Impacts}

COVID-19 has caused unprecedented macro and micro level negative impacts but the most significant impact reported in this regard is that of economic impact across the globe. In today's economically and technologically connected world, no one can be escaped from the economic problems aroused somewhere in the world. Hence, COVID-19 is a global issue and everyone experiences its impact. The United Nation has informed the world earlier that the pandemic is far more than health crises. It will affect societies and economies at its core. At a micro level, the pandemic is perceived to be very much threatening to the survival of the low-income settlement and marginalized population. Other respondents also stated the same views and added:

"The smooth life is badly affected by the burning issue of corona attack. The routine of daily basis labour and daily wagers are suffered and they cannot go outside to earn a livelihood for their children and other dependent members of their family".

Another participant of the study added:

"We depend on meagre resources. We struggle hard to feed out children and family. Our shops are closed and daily wagers are in a difficult condition. Daily wagers and labours are already having difficulty to balance their needs and resources."

Earning the livelihood is very important for the smoothly running of life of every human being. The people of developing and underdeveloped country depend upon their daily basis income (Macionis, Benoit \& Janson, 2000). The people living in the village of quarantine and neighbouring can confront difficulties while in searching for foodstuffs. The people of another area also feel hazards form the people who belong to quarantine or the people living in the surrounding area.

\section{Conclusion}

It is concluded from the study that social isolation and quarantine of a village in District Dir (Lower) has caused a variety of negative implication on the lives of the inhabitants. The most notables of the problems reported by the inhabitants were social crises, psychological impacts and economic repercussions of the administratively imposed restrictions. It is further concluded that the inhabitants are relying on their underdeveloped resources, which has further 
deteriorated through restricted mass mobility and lockdown. The inhabitants are thriving mostly on the support mechanisms, which they unconditionally extend in the time of need, and difficulties but such like practices and mechanism were seriously halted by the pandemic and quarantine. In the imposed lockdown, people are confined to their homes and all the social, economic, religious, political, and familial life is significantly suffered. The psychological implications caused by avoidance of meeting, restricting the business opportunities and daily basis transaction has potentially minimized the chances that has further created economic dependency. The wheel of life is all together stopped due to the appearance of covid-19 and it effect on human body. The government urged to follow the precautionary measure to protect the people from the curse of this disease because no proper treatment has been invented so far. It is recommended that the community should realize the gravity of situation and should come forward to full support the government by following standard operating procedure. On the other hand, the government should come with a concrete policy measure to help the poor and downtrodden community in this time of trouble and turbulence.

\section{References}

Brooks, S. K., Webster R. K., Smith, L. E., Woodland, L., Wessely, S., Greenberg, N., Rubin, G. J. (2020). The Psychological impact of quarantine and how to reduce it: rapid review of the evidence. The Lancet, 395(10227), 912-920. https://doi.org/10.1016/S0140-6736(20)30460-8

Cava, M. A., Fay, K. E., Beanlands, H. J., McCay, E. A., Wignall, R., (2005). The experience of quarantine for individuals affected by SARS in Toronto. Public Health Nursing, 22(5), 398-406. https://doi.org/10.1111/j.0737-1209.2005.220504.X

Chan, J. F. W., Yuan, S., Kok, K. H, To, K. K. W., Chu., H., Yang, J., ... Tsoi, H. W. (2020). A familial cluster of pneumonia associated with the 2019 novel coronavirus indicating person-to-person transmission: a study of a family cluster. The Lancet, 395(10223), 514-23. https://doi.org/10.1016/S0140-6736(20)30154-9

Chen, S., Yang, J., Yang, W., Wang, C., Barnighausen, T. (2020). COVID-19 control in China during mass population movements at New Year. The Lancet, 395(10226), 764-66. https://www.thelancet.com/journals/lancet/article/PIIS0140-6736(20)304219/fulltext

Epko, C., \& Ishaq, A. B. (2016). Islam and the environment: implications of Islamic funeral practice on environmental sustainability. IOSR Journal of Research \& Method in Education. 6(1), 58-63.

Fong, M. W., Gao, H., Wong, J. Y., Xiao, J., Shiu, E. Y., Ryu, S., \& Cowling, B. J. (2020). "No pharmaceutical measures for pandemic influenza in non-healthcare settings: social distancing measures. Emergency, Infection and Disease, 26(5), 976-984. https://doi.10.3201/eid2605.190995

Hens, N. A., Ayele, G. M., Goeyvaerts, N., Aerts, M., Mossong, J., Edmuds, J. W., Beutels, P. (2009). Estimating the impact of school closure on social mixing behaviour and the transmission of close contact infections in eight European countries. BMC Infection and Disease 9(1), 1-12. https://bmcinfectdis.biomedcentral.com/articles/10.1186/1471-2334-9-187

Jeong, H., Yim, H. W., Song, Y. J., Ki, M., Min, J. A., Cho, J., \& Chae, J. H. (2016). Mental health status of people isolated due to Middle East respiratory syndrome. Epidemiology Health, and 38, n.p. https://www.ncbi.nlm.nih.gov/pmc/articles/PMC5177805/ 
Joffe, H., \& Lee, N. L. (2004). Social representation of a food risk: the Hong Kong avian bird flu epidemic. Journal of Health Psychology, 9(4), 517-533.

Li, Q., Guan, X., Wu, P., Wang, X., Zhou, L., Tong, Y., ... \& Xing, X. (2020). Early transmission dynamics in Wuhan, China, of novel coronavirus-infected pneumonia. The New England Journal of Medicine, 382, 1199-1207. https://doi.10.1056/NEJMoa2001316

Macionis, J. J., Benoit, C., \& Jansson, M. (2000). Society: the basics. Prentice Hall.

McCormack, C., \& Jones, D. (1997). Building a web-based education system. John Wiley.

Mossong, J., Hens, N., Jit, M., Beutels, P., Auranen, K., Mikolajczyk, R., ... Heijine, J., (2008). Social contacts and mixing patterns relevant to the spread of infectious diseases. PLoS Medicine, 5(3), e74. https://doi.org/10.1371/journal.pmed.0050074

National Census Survey. (2018). Population and Household Detail From Block to District Level Khyber Pakhtunkhwa (Lower Dir District). 1-61. http://www.pbs.gov.pk/sites/default/files/bwpsr/kp/LOWER\%20DIR_BLOCKWIS E.pdf

Nisar, F., \& Rashid, A. (2019). Religiosity for promotion of behaviour: role of Islamic worships in moral development of Muslim youth. Al-Mill: Journal of Religion and Thought, 1(2), 1-16.

Prem, K., Cook, A. R., Jit, M. (2017). Projecting social contact matrices in 152 countries using contact surveys and demographic data. PLoS Computational Biology, 13(9), e1005697. https://doi.org/10.1371/journal.pcbi.1005697

Quilty, B. J., Clifford, S., Flasche, S., Eggo, R. M. (2020). Effectiveness of airport screening at detecting travellers infected with novel coronavirus (2019-nCoV). Eurosurveillance, 25(5), n.p. https://www.eurosurveillance.org/content/10.2807/15607917.ES.2020.25.5.2000080?fbclid=IwAR0qDoiIqFDHEf2fotEB786i1cxsAvQqJL hx0V7GWpXHaWjr-U7wN2gRkFY

Riou, J. \& Althaus, C. L. (2020). Pattern of early human-to-human transmission of Wuhan 2019-nCoV. bioRxiv, (pre-print). https://doi.org/10.1101/2020.01.23.917351

Tian, H., Li, Y., Liu, Y., Kraemer, M. U., Chen, B., Cai, J., .. \& \& Chui, Y. (2020). Early evaluation of the Wuhan City travel restrictions in response to the 2019 novel coronavirus $\quad$ outbreak. Medrxiv. https://doi.org/:10.1101/2020.01.30.20019844

Warwick, M., \& Roshen, F. (2020). The global macro-economic impact of Covid-19: Seven Scenarios. pp. 1-43. Australian National University; the Brookings Institution; and Centre of Excellence in Population Ageing Reseach. https://www.brookings.edu/wpcontent/uploads/2020/03/20200302_COVID19.pdf

Zhang, J., Klepac, P., Read, J. M., Rosello, A., Wang, X., Lai, S., .. \& \& Yang, J. (2019). Patterns of human social contact and contact with animals in Shanghai, China. Scientific Reports, 9(1), 1-11. https://www.nature.com/articles/s41598-019-51609-8

Zhu, N., Zhang, D., \& Wang, W. (2020). A novel coronavirus from patients with pneumonia in China. The New England Journal of Medicine, n.p. https://doi.org/10.1056/NEJMoa2001017 